\title{
Addressing Soil Degradation and Flood Risk Decision Making in Levee Protected Agricultural Lands under Increasingly Variable Climate Conditions
}

\author{
Lois Wright Morton', Kenneth R. Olson² \\ ${ }^{1}$ Department of Sociology, College of Agriculture and Life Sciences, lowa State University, Ames, lowa, USA \\ ${ }^{2}$ Department of Natural Resources and Environmental Sciences, College of Agricultural, Consumer, and \\ Environmental Sciences, University of Illinois, Urbana, Illinois, USA \\ Email: Iwmorton@iastate.edu, krolson@illinois.edu
}

Received 24 May 2014; revised 21 June 2014; accepted 15 July 2014

Copyright (C) 2014 by authors and Scientific Research Publishing Inc.

This work is licensed under the Creative Commons Attribution International License (CC BY). http://creativecommons.org/licenses/by/4.0/

(c) (i) Open Access

\begin{abstract}
Public and private levee systems may not be robust enough to address flooding risk to agriculture under changing climate conditions. Of concern are levee protected riverine bottomlands with intensive agricultural uses and diminished wetland systems that give resilience to floodplain hydrologic functions. In the United States natural and induced levee breaching has caused soil damage, loss of agricultural productivity, and public tension among agricultural landowners, urban residents, and environmental interests. Risk management and adaptive capacity of this humannatural system could be improved by assessments of 1) soil damage and 2) stakeholder values, fears, and knowledge about the riverine bottomland agroecosystem.
\end{abstract}

\section{Keywords}

Levee Breaching, Soil Damage, Climate Change, Agriculture, Stakeholder Values, Agroecosystem, Flooding

\section{Introduction}

Levee protected agricultural lands are some of the most fertile and productive soils in the world. These lands which are part of the global food security network are highly vulnerable and at risk of riverine flooding and levee breaching under changing climatic conditions. While most types of riverine flooding are known risks with 
repetitive behaviors, a shifting climate can change the frequency, seasonality, and severity of flood events, often in random ways [1] [2]. The uncertainty and nonlinear second and third order effects of the global climate system can amplify or attenuate the non-uniform distribution of precipitation and threaten the integrity of dams, levees and other structures designed to protect land uses adjacent to rivers [3] and alter the resilience of these landscapes.

More than $75 \%$ of the disasters that have occurred globally over the past decade have been triggered by climate and climate related hazards such as floods, storms and drought [4] [5]. In the United States (US) much of the 1993 flooding was associated with sand boils and structural failure of levees (rather than overtopping) due to prolonged high flood stages and unusually large runoff in systems that were cut off from historical flood plains [2]. Flooding of agricultural lands, particularly those adjacent to rivers and their alluvial plains, can have high impact and persistent effects on soil erosion and degradation, crop productivity, economic, social, and ecological conditions. The 2007 and 2014 Intergovernmental Panel on Climate Change (IPCC) Reports concluded that current water management practices may not be robust enough to cope with impacts of climate change and draws specific attention to flooding risk in agriculture and ecological systems [6] [7]. For example, the Mississippi River Basin which drains more than $41 \%$ of the continental US experienced major flooding and levee breaching in 1993 and 2011 with damage in the billions of dollars to levees, agriculture, livestock, fields, farm buildings and equipment [2] [3] [8].

Resilience in the context of disaster management is the capacity of the floodplain system to absorb disturbances such as flooding and still retain basic social, economic, and ecosystem functions [4] [9]. Park, Seager, Rao, Convertino and Linkov [10] call for risk management engineering that moves beyond risk minimization and strengthening physical infrastructures toward system resilience goals and strategies that provide information feedback loops to minimize the consequences of failure and increase the flexibility of engineered, natural, and social systems to respond to uncertain and unpredictable conditions. This suggests the need for new risk and resilience approaches to managing leveed agroecosystems that, in conjunction with reliance on structural solutions, embrace adaptive management strategies which assess 1) changing soil conditions and land uses from levee breaching, and 2) local and regional stakeholder values, fears, social, and economic conditions [10] [11]. These assessments can provide valuable feedback to improve capacity building and adaptive management that accomplish multifunctional goals. In this paper riverine bottomland flooding and vulnerability to levee breaching in the US are discussed followed by a case study of southeast Missouri (Bootheel) leveed agricultural lands. Historical land use patterns of leveed lands and the Great Flood of 2011 on the Mississippi River are used to illustrate the impacts of flooding and levee breaching on soil conditions and agricultural productivity as well as public tensions associated with recovery and reconstruction. We recommend that scientific assessment of soil damage and crop productivity, riverine ecosystems, and uncertainty in climate conditions be linked to diverse public values to improve decision making that deals with facts and values.

\section{US Riverine Bottomland Flooding and Vulnerability to Levee Breaching}

The US Army Corps of Engineers (USACE) manages more than 22,533 km (14,000 mi) of levees protecting bottomlands in river plains, approximately 700 dams, and 19,314 km (12,000 mi) of river navigation channel and control structures with goals that include supporting flood risk management activities in communities and restoring aquatic ecosystems [12]. In addition to these federal levee systems, there are many more privately owned levee systems protecting agricultural lands, rural residents, and urban communities. Many of these levees are financed, built, and maintained cooperatively at the watershed level by local farmers and communities to protect their livelihoods and shared community infrastructures. Extreme flooding events such as the 1927, 1937, 1993, 2002, 2008 and 2011 floods along the Ohio and Mississippi rivers and their tributaries illustrate the continuing difficulties facing river communities, industry and agriculture [8] [13]-[15]. Public agencies and private organizations are challenged to anticipate risk and manage emergencies related to evolving natural disasters, downstream flooding and increased water pressure on levee protected bottomlands [3] [11] [16]-[20].

The USACE 2010 National Report iterates the substantive evidence that changing climate conditions will increase the frequency and severity of extreme weather events leading to expectations that 50, 100 and 500 year flood events will occur more often [1] [21]. Of particular concern is the vulnerability of low-lying deltaic environments that rely on levee protection and the direct impacts of levee breaching on hydrologic patterns, sedi- 
ment transport and distribution, soil erosion, land scouring, and indirect impacts on social and economic activities, especially agriculture, of flooded areas.

\section{Leveed River Bottoms}

River bottomlands are low, flat areas adjacent to a river or stream and subject to periodic flooding during high water events. Leveed river bottomlands are designed to protect human populations and various land uses including agriculture from river flooding. When a levee fails the damage caused by floodwaters and contamination of water and land is significant. Water borne sediments often cover plants and soils and fill in road ditches, drainage ditches and waterways or re-enter water in rivers, streams and lakes. Frequently crater lakes are created by floodwaters either topping or pouring through the levee breach and substantive gully development [16]. These gullies and land scour areas can extend into the floodplain several kilometers beyond the breach into fields or along ridges [2] [8]. As the water slows, the coarse sediments such as sand are deposited first on the alluvial soils followed by silt and clay.

Sediment is the primary water pollutant on a mass basis and the sediment often carries with it other nutrients and pollutants including pathogens, hydrocarbons and pesticides. Once fields dry out, thin sediment deposits may be incorporated into the soil with tillage and the effects on soil productivity and crop production are thought to be minimal. However, thick sediment deposits such as sand deltas require piling up and removal to restore agricultural functionality [8] [18], and the productivity of these soils including their capacity to hold moisture under future drought conditions compared to the original soils has not been measured. The land scouring and erosional processes remove topsoil, create eroded phases and depositional phases on a soil and sometimes subsoil and result in less productive soils even if land is re-shaped and reclaimed [22] [23]. In addition, the sediment can block highway and drainage ditches and make it difficult to remove excess water from the poorly drained soils and return the land to agricultural production.

Whenever bottomlands along rivers are flooded, public and private waters and lands in the watershed are affected. The soil types, hydrogeologic features, volume of flow, time of year, agricultural use of fertilizers, pesticides, and other chemicals as well as upstream point sources such as sewage treatment plants, storm sewer drainage and other urban land uses affect the extent of land scouring and sedimentation and fine scale remediation needed [24]. Floodwater can also damage surface and subsurface water and impact water tables within the watershed. Effects of sediment deposition and land scouring on soil profiles and productivity are often unknown making it difficult for agency technical staff, local leadership, and farmers to have sufficient information to effectively restore soil productivity and put in place strategies and infrastructure to prepare for future flood events.

Most research related to the impact of flooding on floodplain soils has focused on natural seasonal flood events where the inundation and subsequent drainage of the land occurs as a relatively slow, low-energy process. In contrast, levee breaches result in a very fast, high-energy release of large quantities of water onto the floodplain. A closer examination of the New Madrid Floodway, Missouri and the USACE induced breaching during the 2011 Ohio and Mississippi rivers flood offers an opportunity to assess riverine flood conditions, impacts of levee breaching on agricultural lands, and the social tensions associated with managing leveed landscapes.

\section{New Madrid Floodway, Missouri}

\subsection{Historical Land Uses}

The New Madrid Floodway located immediately south west of the confluence of the Mississippi and the Ohio rivers at Cairo, Illinois (Figure 1) at $84.5 \mathrm{~m}(279 \mathrm{ft}$ ) above sea level was designed by the USACE in the aftermath of the deadly 1927 flood [8] [13] [25]. Built under the authority of the Flood Control Act of 1928 (70th US Congress, Session 1 Chapter 596, enacted May 15, 1928) [26], the Floodway is approximately $53.1 \mathrm{~km}(33 \mathrm{mi})$ long and is between $6.4 \mathrm{~km} \mathrm{(4} \mathrm{mi)} \mathrm{and} 16.1 \mathrm{~km}(10 \mathrm{mi})$ wide covering almost 53,824 ha (133,000 ac) of river bottomlands in the Bootheel of Missouri. The frontline levee, which forms the eastern boundary of the Floodway, protects land uses within the Floodway until the Mississippi River reaches the $16.8 \mathrm{~m}(55 \mathrm{ft})$ stage, at which time the floodwater can naturally overtop the frontline levee. The USACE obtained easements between 1928 and 1932 from the land owners giving the Corps the right to pass floodwater into and through the New Madrid Floodway. The Flood Control Act of 1965 authorized modification of the New Madrid Floodway operational plan and levees were raised and new easements were obtained. When the Ohio River peak forecast is pre- 


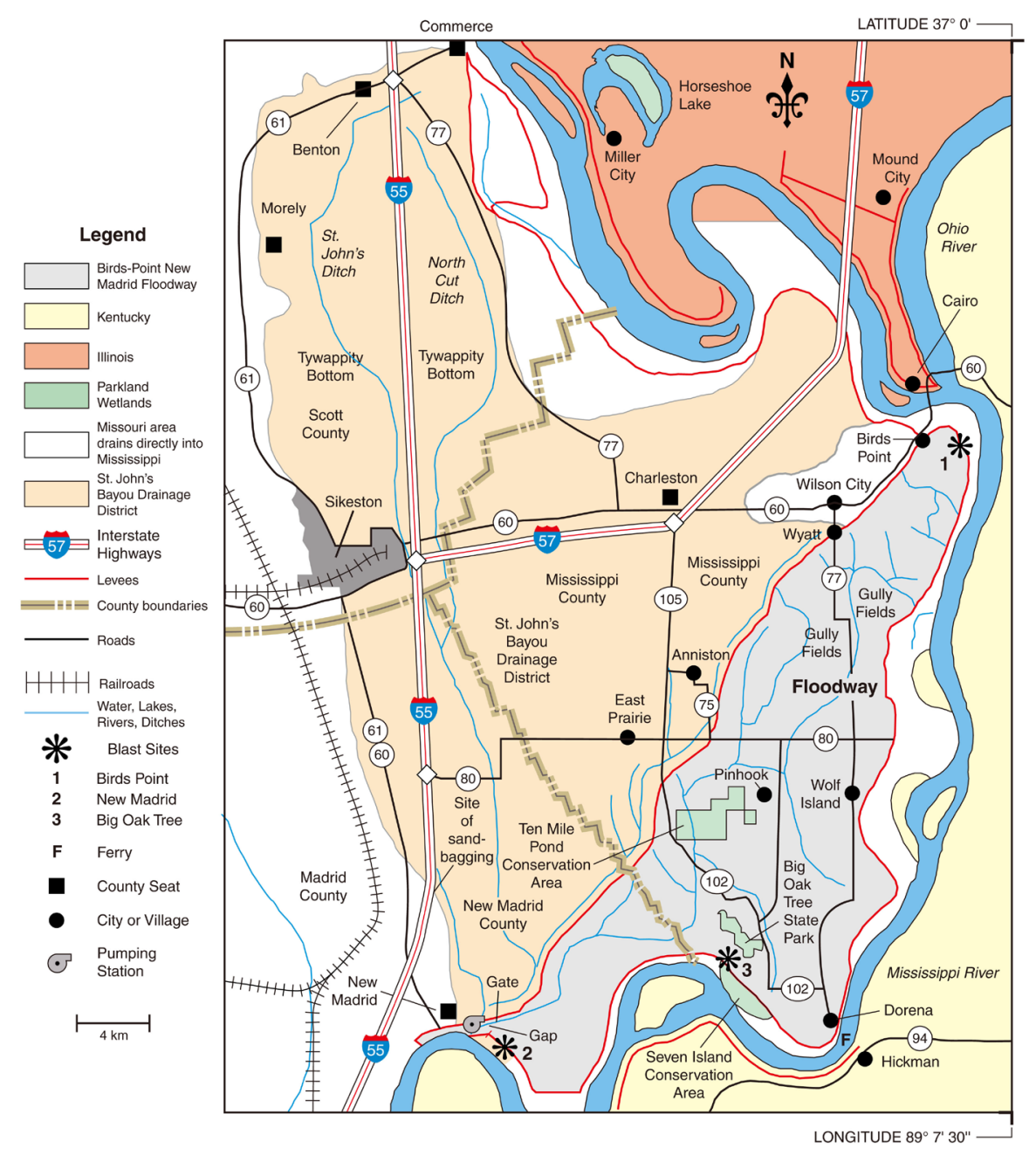

Figure 1. Map of New Madrid Floodway and system of levees.

dicted to reach $18.3 \mathrm{~m}$ (60 ft) or higher on the Cairo gage, the USACE has legal capacity to deliberately breach the New Madrid Floodway frontline levee to reduce pressure on the Cairo levee system and protect other cities and levees [8].

A look at the historical land use patterns of Mississippi river bottomlands place in perspective the implications and impacts of induced and natural breaching on levee protected lands. Prior to settlement, the Missouri Bootheel contained more than half of all the state of Missouri's original 1.9 million ha (4.8 million ac) of wetlands; over time, almost all of these acres of wetlands and forested bottomlands were cleared, drained, and leveled for production agriculture, leaving 320,000 ha (800,000 ac) of wetlands in Missouri in 2013 [27]. The evolution of the New Madrid Floodway from forested bottomlands to productive agricultural lands is reflected in the land use change patterns (1930-2007) of New Madrid and Mississippi Counties (Figure 2), a portion of which are levee protected lands within the New Madrid Floodway. The US Census of Agriculture [28] farmer reported data for New Madrid and Mississippi Counties show 6,510 farms with 135,595 ha (338,988 ac) in harvested cropland and 7805 ha $(19,513 \mathrm{ac})$ of woodland pasture in 1935. Seventy-two years later, in 2007, there were 578 farms of record, harvested cropland acres had almost doubled 244,400 ha (610,979 ac) and woodland pasture substantively decreased to 55.6 ha $(139 \mathrm{ac})$. Additional draining of wetlands provided a large portion of the increase in cropland acres. Although corn, soybean, wheat, cotton, and rice are the main cultivated crops in this region, an intensification of soybean production can be observed from 1945 to 2007 (Figure 3) making it the dominant crop in the two counties. This increase in soybean production likely reflects farmer adaptive management responses to seasonal wetness and flooding in these bottomlands as the soybean can be planted in 


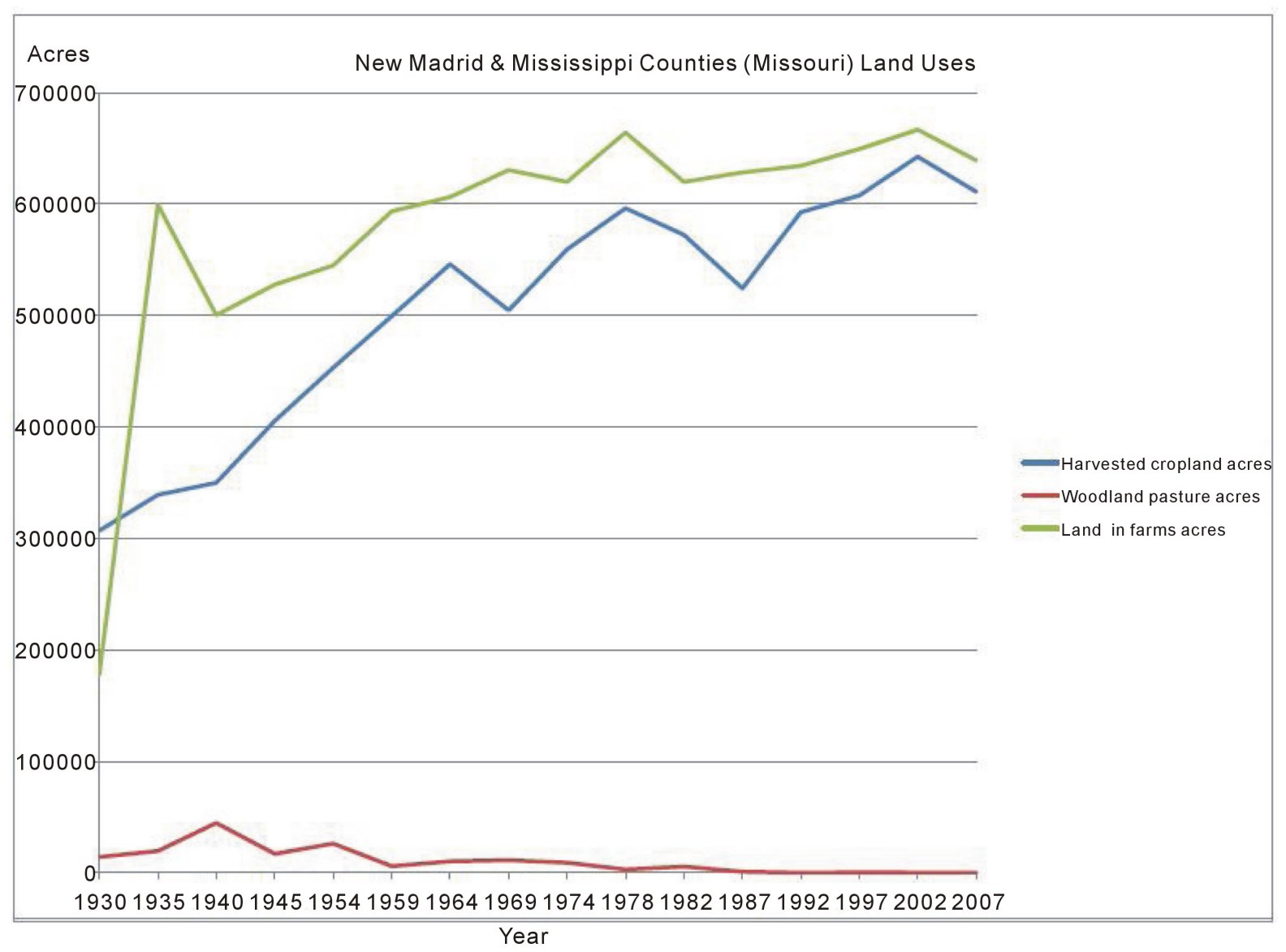

Figure 2. New Madrid and Mississippi Counties (Missouri) land uses USDA census of agriculture 1930-2007 [28].

early summer after saturated and flooded soils have drained.

\subsection{Soil Functional Uses and Productivity}

The characteristics of different soil series affect the functional uses and ecosystem services which the soil provides [29]. These functional uses can be altered by flooding processes when land is eroded by fast moving water and the soil is redistributed to a new location when silt is deposited as sediment laden water slows down [2]. Flooding can have beneficial effects-replenishing agricultural soils with new nutrients and transporting sediment downstream to maintain delta and coastal areas [2]. However, flooding can also leave behind infertile sand and degraded soils, thus changing the soil functionality to a less than optimal state as soil organic matter (SOM) is lost. SOM is previously living plant and animal residues in different stages of decomposition found in the upper $20 \mathrm{~cm}$ of soil. When SOM is lost, soil aggregation is reduced and important nutrients needed for agricultural plant growth and development are less likely to be available. Alterations in soil functionality can change its ability to sustain biological activity and productivity, regulate water, filter nutrients, buffer and detoxify organic and inorganic materials, and store and cycle nutrients [29]. These soil activities are critical to the floodplain system, affecting not only future agricultural productivity but also riparian wetlands that are the hydrological and biogeochemical buffers in the floodplain [2] [19].

The types of vegetation present and the route flood waters take can affect changes in soil characteristics and significantly influence the scouring and deposition of sediments during a flood event, especially when the floodwater carries a large amount of energy [8] [30]. For example, during the 2011 Mississippi River Flood when the USACE induced the breaching of the Birds Point-New Madrid levee system, the field closest to the breach contained a healthy stand of winter wheat and the soil was mostly protected from scouring, whereas an adjacent recently tilled field further from the breach was severely impacted by scouring and loss of topsoil [8]. There is a 


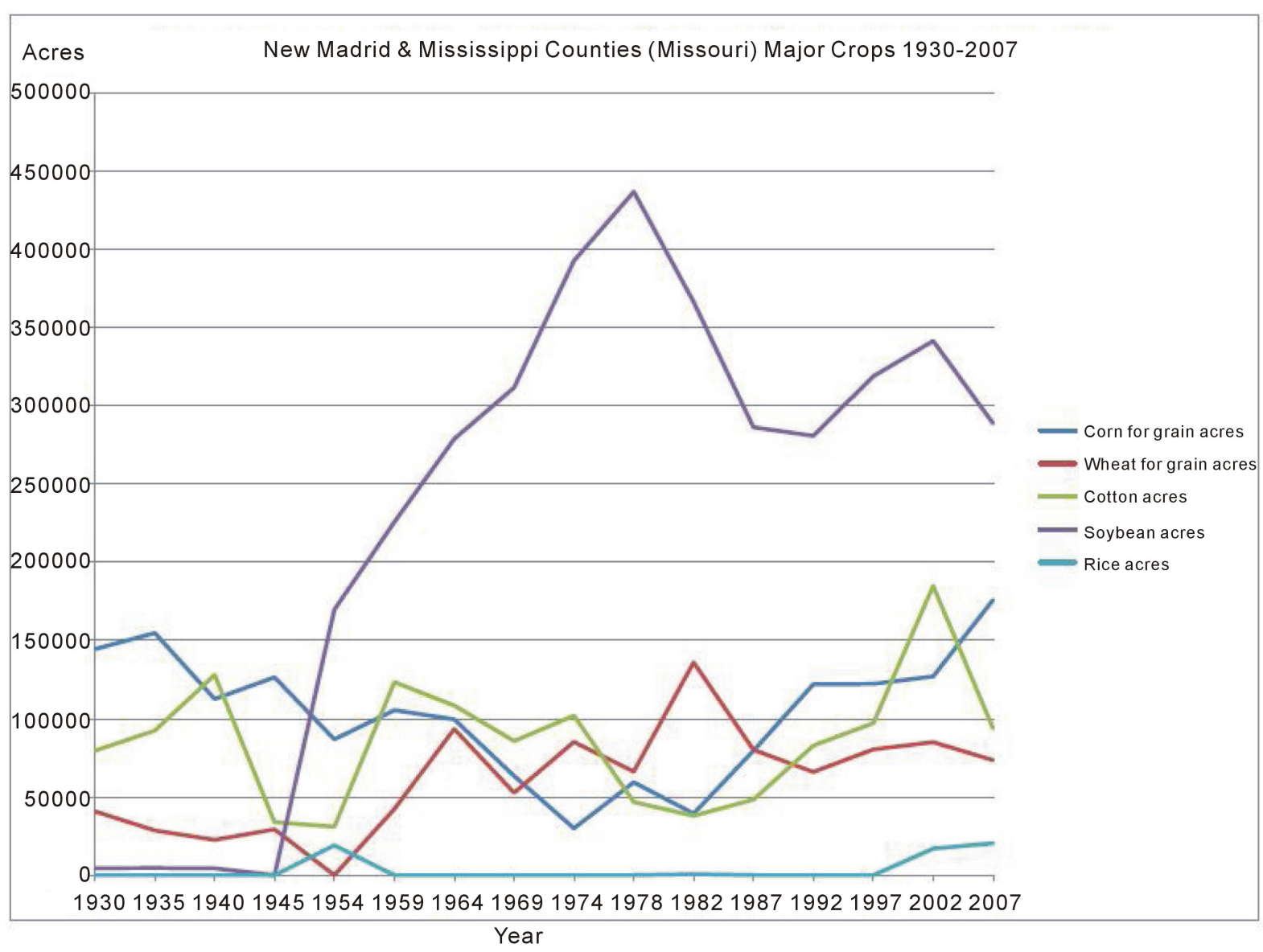

Figure 3. New Madrid and Mississippi Counties (Missouri) major crops 1930-2007 USDA census of agriculture [28].

natural feedback cycle between vegetation and hydrology in floodplains; floods strongly influence the structure and composition of the vegetation, but vegetation contributes to hydraulic roughness and influences patterns of sediment deposition [31]. This cycle and the relationships among natural and planted vegetation can be disrupted by natural and human changes in river hydrology. Figure 4 and Figure 5 illustrate the land scouring, soil erosion and deep gullies in agricultural lands that can result from levee breaching and flooding when heavy rains and late snow melt converge to create prolonged high floodwaters and intense water pressure that undermine levee structures and threaten failure [17].

\subsection{O'Bryan Ridge Gully Fields and Impacts on Soil Productivity}

The Mississippi River 2011 Flood led to private levee breaches (e.g. Len Small farmers’ levee in Illinois and Commerce, Missouri farmers' levee); mega sand boils in the City of Cairo, Illinois which weakened the floodwall and led to evacuation of residents; flooding of agricultural bottomlands without levees along the Ohio River in Kentucky, Ohio, and Illinois; and substantively weakened the USACE levee systems south of the Mississippi and Ohio rivers confluence threatening downstream rural land and urban communities [17] [19]. As a result, the USACE activated their emergency relief plan of placing in use the New Madrid Floodway when the Ohio River reached $18.7 \mathrm{~m}$ (61.72 ft) on the Cairo, Illinois Flood gage. On May 2, 2011 six sections of the Birds Point levee totaling approximately $1.9 \mathrm{~km}(1.2 \mathrm{mi})$ were deliberately breached to allow more than one fourth of the flood —swollen Mississippi River to enter the $56 \mathrm{~km}$ (35 mi) long and 6.4 to $16 \mathrm{~km}$ (4 to $10 \mathrm{mi}$ ) wide Birds Point to New Madrid Floodway. Initially, $4 \mathrm{~m}$ (13.1 ft) of water over $2 \mathrm{~km}$ (1.2 mi) wide rushed into the Floodway and overnight flowed to the gap located northeast of New Madrid (see Figure 1) [8] [25]. As the floodwaters spread out, the height of the advancing water front dropped to about 1 to $2 \mathrm{~m}$ (3.3 to $6.6 \mathrm{ft}$ ).

Approximately $8 \mathrm{~km}(5 \mathrm{mi})$ to the southeast, the advancing floodwaters started to pond in front of O’Bryan 


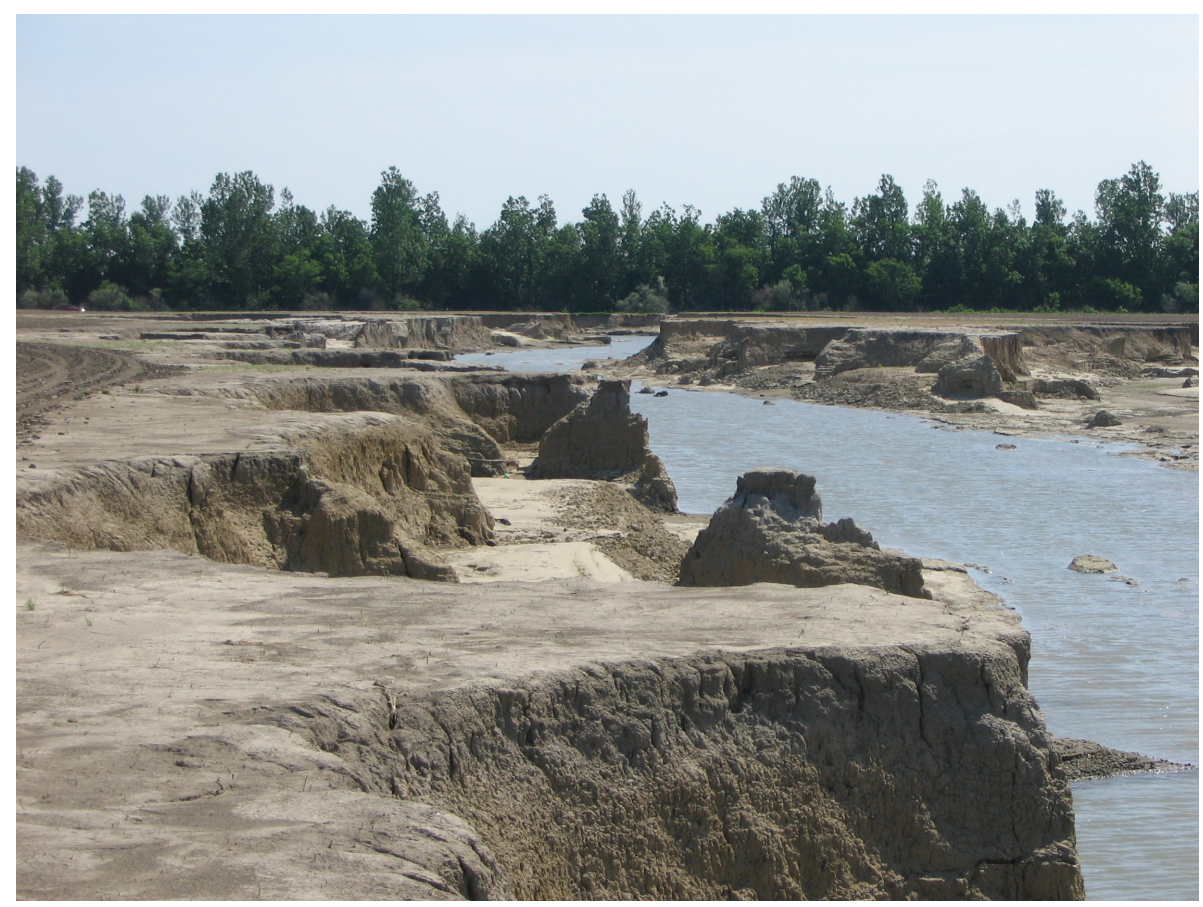

Figure 4. O’Bryan Ridge gully field, June 2011 after the May $2^{\text {nd }}$ USACE induced breaching of Birds Point-New Madrid levee.

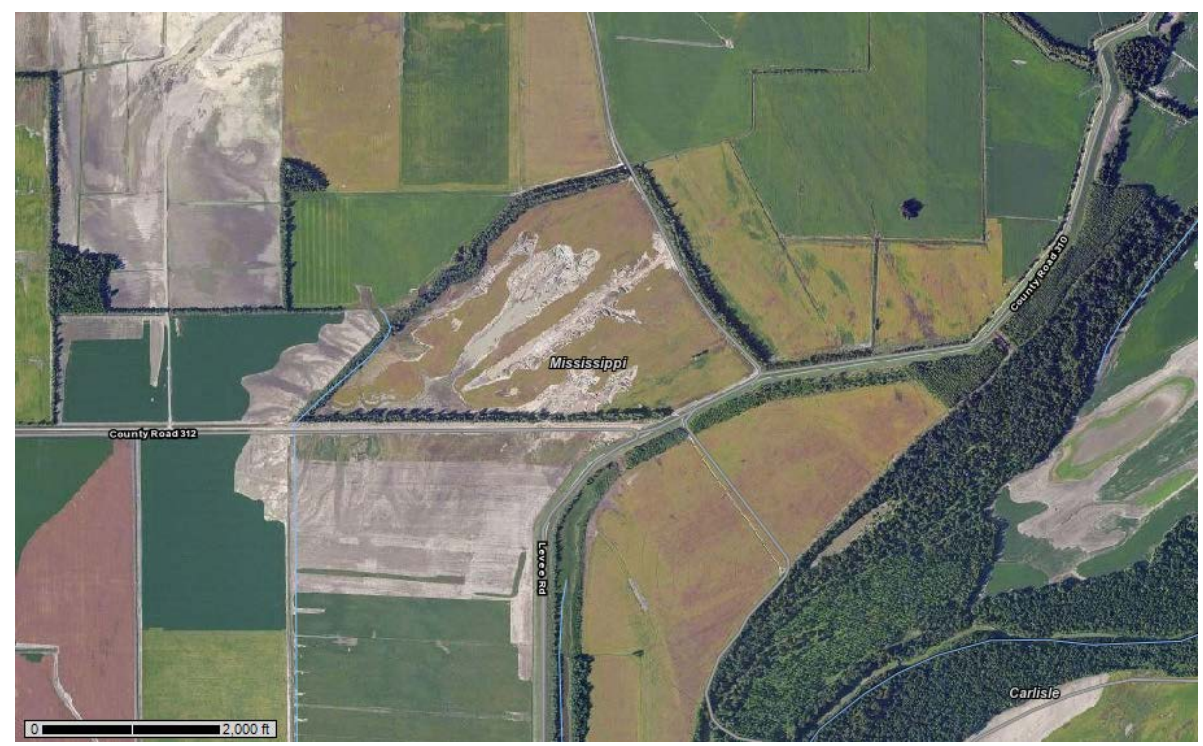

Figure 5. 2011 Aerial view of O’Bryan Ridge gully fields and scouring extending under road and into the levee and drainage district land after 2011 USACE induced levee breaching at Birds Point New Madrid Floodway.

Ridge (Figure 5) a former meander bank about 2 to $2.5 \mathrm{~m}$ (6.6 to $8.3 \mathrm{ft}$ ) high. Floodwaters then flowed over O'Bryan Ridge which is about $10 \mathrm{~km}(6 \mathrm{mi})$ long and approximately $1 \mathrm{~km}(0.6 \mathrm{~m})$ wide [16]. As the floodwater spread across the 2010 soybean residue in the fields of O'Bryan Ridge, rapidly moving water scoured the land surface before dropping to the first bottom on the west side of the ridge.

The disastrous consequences of the floodwater dropping 2 to $2.5 \mathrm{~m}$ (6.6 to $8.3 \mathrm{ft}$ ) were likely not anticipated since the Floodway had not been used since 1937. The floodwater dropped off O’Bryan Ridge and concentrated in lower preexisting water drainage ways. The concentrated floodwater flowed east to west and cut into the ridge 
and eventually, as a result of a hydraulic jump, cut long, canyon size gullies up to $1 \mathrm{~km}$ (0.6 mi) in length (Figure 5). The bottom of the newly formed trenches were more than one meter below the first bottom surface and $3.6 \mathrm{~m}$ (12 ft) below the surface of O’Bryan Ridge [16]. A $1 \mathrm{~km}(0.6 \mathrm{mi})$ channel cut west to east and undercut the gravel road (CR 310) into the treelined first bottom border area. The series of canyon sized gullies (Figure 4) created a dendritic pattern across the former soybean field; and other gullies cut through the tree line and undercut CR 312 on the south of O’Bryan Ridge adjacent the frontline levee.

\subsection{Land Scouring Impacts on Agricultural Production, Soil Productivity, and Land Use}

Prior to the Floodway opening, the O’Bryan Ridge gully field was planted to soybean on 78 ha (195 ac) and produced approximately $131 \mathrm{mt}$ (8550 bu) of soybean per year. After the 2011 induced breach, the gullies and areas between the deep gullies could not be planted and the remainder of the field was land scoured (Figure 5). In 2013 the ridgetop topsoil, subsoil and parent materials of the soils at the gully edges were graded and pushed into the gully bottoms creating sloping man-made soils (Udifluvents). The sloping Udifluvents were replanted into soybean and the gully bottoms became natural wetlands and ponds. The productivity of the land-scoured soils was lowered with soybean production yields reduced to about $2.5 \mathrm{mt} / \mathrm{ha}$ (37 bu/ac) for $53.6 \mathrm{ha}$ (134 ac) of agricultural land and $0 \mathrm{mt} / \mathrm{ha}(0 \mathrm{bu} / \mathrm{ac})$ for the remaining 24 ha $(61 \mathrm{ac})$ of wetlands and ponds. This loss of agricultural production and soil productivity on the land scoured, reshaped area, wetlands and ponds is permanent without extensive additional restoration activities. Therefore, the Levee District No. 3's O'Bryan gully field which in 2010 produced $131 \mathrm{mt} / \mathrm{ha} / \mathrm{yr}$ (8550 bu/yr) of soybean per year is now producing $75.4 \mathrm{mt} / \mathrm{ha} / \mathrm{yr}$ (4920 $\mathrm{bu} / \mathrm{yr}$ ) representing a loss of $55.6 \mathrm{mt} / \mathrm{ha} / \mathrm{yr}$ (3630 bu) or $42 \%$ of the average annual soybean production. The 2013 regrading resulted in a loss of 24 ha (61 ac) of cropland and a gain of 16 ha (40 ac) of wetlands and 8 ha (21 ac) of ponds.

The Udifluvents slope had little soil organic carbon matter and aggregation in the surface layer. These manmade soils are now on 2 to 6 percent slope with an erosion rate above $66 \mathrm{mt} / \mathrm{ha}$ (30 tons/ac). Many rills were created in 2013 as a result of soybean production on these sloping soils. A conservation plan is needed for this area. The new sloping land is too erosive and no longer suited to soybean production without extensive conservation practices. A terrace system and contour farming are needed to sustain productivity of soybean or corn in the crop rotation. No till management does not provide a method to eliminate annual rills which will quickly turn into new gullies. Further, the crop rotation should not be continuous soybean as it has been for at least the last four years (2010 to 2013) as this will exacerbate erosion. The problem of a continuous soybean rotation and erosion can be addressed with a rotation that includes wheat and perhaps forages. Winter wheat and cover crops provide a protective vegetative cover during the non-growing season. The middle and lowest part of the gullies are no longer suitable for row crops and represent a significant land use change with 31\% of the previous agricultural land becoming wetlands and ponds.

In 2013, the main $1 \mathrm{~km}(0.6 \mathrm{mi})$ gully remains open for the next New Madrid Floodway use. However CR 310 was re-constructed across the large gully without a culvert and this road would block the use of the gully as a waterway in the future. During the next Floodway use, the floodwaters will likely pond in front of O'Bryan Ridge, just like they did in 2011, and eventually top CR 310 and flow into the gully field where water would concentrate in the existing gullies and cut and extend them to the east and dissect CR 310 in many more places. Future reclamation efforts would be required and could result in even more conversion of agricultural lands to wetlands and ponds. Levee District No. 3 plans to drain existing pond with excavator created drainage ditches and to fill in the wetland in an attempt to restore the 78 ha (195 ac) field to agricultural use. The re-constructed soil and the soils with topsoil removal will have significantly lower soil productivity than the original soils before the 2011 Floodway use. The gully field area needs a conservation plan. The productivity loss is permanent.

\subsection{Tension among Competing Economic, Ecological, and Geographical Interests}

Levee structures and the agroecosystems they protect are shaped by local landowners and regional organizations and agencies representing diverse land use priorities and expectations for riverine bottomlands. Social values, fears of flooding and loss of property and life, and the management decisions that reflect these concerns are not static but shift as experiences with minor and major flooding events occur, as new science and technologies are available to protect preferred land uses, and as the multifunctional roles of river ecosystems are better understood. The New Madrid Floodway watershed is probably the most litigated watershed in the Mississippi River 
Valley. A 140-farmer lawsuit in federal court for soil damages sustained when the Floodway was opened in 2011 continues through the court system.

In recent history, there have been three other lawsuits: in 1983 a farmer filed suit to challenge the use of explosives when opening the Floodway (Story vs. Walsh); in 2006 the Wildlife Defense Fund filed a suit to restore water flow to wetlands by removing a levee built in 2005 to close a gap northeast of the town of New Madrid (cost of 17 million dollars to create and remove the levee); and in 2011 the Missouri Attorney General attempted unsuccessfully to block the opening of the Floodway. This watershed has received some of the most federal dollars (e.g. 50 million dollars from 2011 to 2014 for repairs and restoration) ever spent on levee, Floodway and drainage projects in the Mississippi River Valley in addition to substantive state and local public and private dollars. These costs do not include the annual maintenance costs of the Mississippi River Commission (MRC) and USACE since 1932. Congress is currently considering funding for a new 170 million dollar proposal for the St. Johns Bayou drainage district to close the gap again and build pump stations and more gates to create an outlet for the drainage district to the Mississippi River.

\subsection{Engaging the Public}

Recent natural and human-made disasters like levee breaching accentuate the increasing social, economic, and environmental conflicts that surround leveed riverine bottomlands. In addition to the emergency and reconstruction efforts associated with lands flooded and levees breached, local stakeholders and regional and federal entities must plan forward to mitigate future flood disasters. The complexity of federal, regional, state, and local regulatory oversight and management responsibilities for the river, levee systems, and adjacent public and private land uses complicate public decision making and effective governance. This forward planning takes strong leadership and extensive cooperative management effort at several scales that are not always understood or welcomed by people who have a stake in the how the landscape is managed [3].

Public hearings held by the USACE in August 2013 to discuss St. Johns Bayou-New Madrid Floodway proposals to reduce the number of days communities are isolated by floodwaters, reduce crop and non-crop agricultural damages, and reduce critical infrastructure damages to streets and roads illustrate the difficulty in finding consensus among competing sectorial and geographic interests [32] [33]. While the overall goals of the USACE alternative mitigation proposals articulated stakeholder shared concerns, strategies for achieving them revealed strident urban-rural, up-river-down-river, and agricultural-environmental divides including differences in cultures, values, and locational impacts. The agricultural landowners of the Floodway were particularly angry about outside environmentalist testimonies claiming that migratory bird populations and wetland habitats were a great concern and of equal value compared to agricultural production uses. Up-river Cairo homeowners wanted reassurance that the Floodway would continue to be used under future extreme events and were fearful intensified agricultural land use would make the decision politically difficult. These competing values and views are apparent in the USACE public hearing testimonies:

Floodway landowner

I want to take a brief moment and talk about agricultural growth of this region... We have capitalized, well-educated farmers. This region could be the most productive agricultural region in North America, especially given what California is doing with the Central Valley. This region is prone to bring in more agribusinesses to relocate here... We now have thousands of acres of sweet potatoes grown in this region, thousands of acres of potatoes... almost a quarter million acres of rice... the River is the gateway to Asian markets.

\section{Cairo homeowner}

I am from Illinois, and there were some comments made here tonight about not blowing the levee. I want to say - blow the levee. The land was bought for that. This is the face that comes from a town that... was almost destroyed... when you start talking about moving in the new stuff, the building up of this area... that frightens us in Illinois, the more that moves in here, the harder it's going to be to get that levee blown. I want you to know... three foot of water in my home... day and night we didn't stop sandbagging.

Hazard mitigation and regional planning that sets a goal of local capacity to tolerate and overcome damage, adapt to diminished land use productivity, and adjust quality of life when extreme events occur must seek wide participation of those who have a stake in decisions [3]. Good decision making must be factually competent, as- 
sess the values of people associated with the decision, and be able to adapt to uncertainty as understanding of scientific facts and values change [34]. Required public hearings are one way a democracy obtains information about stakeholder beliefs, concerns, and opinions but alone are insufficient in guiding adaptive management. Full consensus is difficult and often not achievable or even desirable as there is frequently a strong preference for self-interest, the status quo, and a lack of knowledge about the floodplain as an ecological system [3] [35]. Despite tensions associated with stakeholder differences, participatory processes are valuable in providing a common platform for making information available to all sectors and encouraging community identification of the problems and shared responsibility for finding solutions [36]. Dietz [34] calls for analytic deliberative processes that link scientific information to public deliberation. Although changes in values and shifts from self-interest to altruism are long term processes, people can change beliefs about facts because "we hold to norms that tell us beliefs should change with new evidence: a norm that comes from science” ([34] p. 14085). Public deliberative processes offer opportunities to communicate the problem of uncertainty, facts associated with managing riverine ecosystems under changing climate conditions, and the diverse values of stakeholders.

Local public agencies and private stakeholders with intermediary land use and water management responsibilities (e.g. levee districts, planning commissions, soil and water conservation districts) can be barriers or bridges that facilitate the linking of scientific facts and social values. They are key conduits of information exchange among local landowners and residents, federal and state agencies, and non-local publics with specific, larger societal interests. They play central roles in assessing the social, economic, and biogeophysical situation after disaster events, communicating known science about soil, hydrology, wetlands and agricultural landscapes, and proposing a variety of solutions to reduce future vulnerability and risk. They can also facilitate trust among sectors and between citizens and government agencies so resources can be mobilized [2]. Social distrust of government is a major barrier to developing resilient, diversified river bottom landscapes with wetland and agricultural uses [35]. Trust is essential if adaptive management policies are to effectively combine engineering solutions with resilience-based management that reduces risk and vulnerability of levee protected agroecosystems.

\subsection{Generating New Solutions}

Purposeful stakeholder engagement not only offers an information forum but can also generate new solutions. One public testimony to the 2013 USACE mitigation proposal noted that the agency environmental report,

... did not contain an agronomic section where these details would be discussed... the economic opportunity cost of not providing the option of using a corn-soybean; corn-soybean-soybean; or corn-wheat-soybean rotation should be factored... it would be reasonable to figure the cost of potential crop productivity losses from increased crop pests when a single crop is used over the years.

Further the testimony asserted, “... this is an important over sight, as demonstrated in the report's economic section..." The economic report referenced notes, "key assumptions are missing”, notably evidence of current agricultural production.

A main concern underlying this testimony is the need for data and assessments that can guide adaptive management in the context of reconstruction after flooding and the re-evaluation of land uses for increased resilience to future disruptions. Adaptive management can be defined as social, economic, and biogeophysical adjustments to past events such as flooding disasters, or adjustments in anticipation of future hazards and risks [37]. Planning that accomplishes adaptive management integrates engineering risk and broader landscape resilience approaches that include comprehensive assessments pre and post flooding events such as soil characterization and degradation, hydrology, and wetland habitats that underpin basic ecological functions and social and economic assessments [10] [11] [38]. The 2011 Flood event and the New Madrid Floodway levee breaching and reconstruction provide important lessons in developing public policies that are responsive to the complexity of the coupled human-natural system at local, regional and national scales.

\section{Public Policy and Adaptive Management}

Climatological predictions suggest that extreme weather events will become more frequent [39] [40], and thus the increased occurrence of catastrophic flooding events in the Mississippi River Basin seems inevitable [41]. As the probabilities for certain types of weather extremes increase in a changing climate, farmers, rural residents and supporting institutions as well as public and private levee districts will need short- and long-term strategies and 
supporting policies to sustain their systems of levees, address breaching events and reclamation of agricultural lands, and put in place adaptive management plans that anticipate future events. Levees are complex engineered systems linked to riverine systems, wetland and agricultural systems, and social systems. Due to incomplete knowledge of these dynamic systems and how they interact, future levee re-designs must not only account for risks to the engineered system but also risks and uncertainty associated with social, economic, soil and hydrological conditions, and land use to achieve resilience [10] [11].

\subsection{Soil Assessment as Part of Resilience Analysis}

Many current water management strategies associated with levee protected agricultural systems are dominated by risk analysis and engineered solutions designed to solve short term risk of flooding and breaching while overlooking resilience design for the agroecosystem as a whole [10]. According to Park et al. [10] resilience analysis assumes there are unknown risks that can't be planned for and focuses on preparing for emergent and unexpected events by continuously gathering new information and using new data as a feedback loop for adaptation as conditions change. In agricultural leveed landscapes new information about soil damage and agronomic impacts from breaching and flooding is needed each time a levee fails.

Soil condition assessments as part of the resilience analysis would offer 1) improved delineation of eroded and depositional soils associated with levee breaching, 2) better measurements of soil deposition and land scouring, and 3) finer resolution mapping of key hydro geologic features. These assessments would increase the capacity of the USACE, local Natural Resource Conservation Service (NRCS) technical specialists, Extension agronomists, Soil and Water Conservation District commissioners, and levee district leadership to not only address short-term structural repairs but also put in place strategic landscape level designs that balance production agriculture and wetland ecosystem services needed to improve the resilience of the agroecosystem.

New spatial technologies such as GIS, Lidar, and remote sensing are tools for assessing disasters [16] [42] and building a hazard information data base to guide decision making for preparedness, response, and recovery. GIS utilizes spatially referenced data, integrating these data into electronic digital maps. Remote sensing data are obtained from sensors on fixed wing aircraft and satellite links and provide earth surface imagery. These technologies hold great potential to assess current conditions and develop models for scenarios to guide future flooding and levee breaching disaster preparedness.

However, these technologies are dependent upon accurate soil survey data. Many of the published US county soil survey maps are one-time surveys, 1 to 30 years old. At best they reflect eroded conditions, deposition and degradation at the time the soil survey was made. Changes that have occurred from land use practices (cultivation of marginal lands, drainage of wetlands, poor agricultural management practices) or from subsequent flood events are not reflected on the published soil maps. Levee breaching and flooding and their impacts on soil and soil productivity need to be documented in an updated soil survey. Restoration plans can be developed based on these updated soil surveys which would include areas where permanent soil productivity losses occurred, where levees are damaged or abandoned, location of crater lakes, gullies, thick sand deposits, sediment filled drainage and road ditches and land scouring. Soil degradation may be so severe in some locations, such as the gully field on O'Bryan Ridge that the land use has to change, from agricultural use to wetlands with a loss in agricultural production and soil productivity. The soil survey report and maps are also the basis for developing soil and water conservation plans and any flooding damages to the soils that result in changes in soil series, location of reconstructed soils and eroded and depositional phases of existing soils.

Continuous updating of the National Soil Survey is congruent with the Committee on Increasing National Resilience to Hazards and Disasters recommendation to establish a disaster-related database to better quantify risk models and structural vulnerability ([43] p. 8). This recommendation for soils could be implemented by an agreement between the US Army Corps of Engineers (USACE) and the US Department of Agriculture (USDA), Natural Resource Conservation Service (NRCS) to insure a rapid federal response after the levee breach and the flooding. This could be part of the federal government response to a disaster which provides emergency funds for restoration work including drainage ditch opening, levee repairs, crater lakes filling, gully repairs and sand deposit removal.

\subsection{Assessments of Stakeholder Values, Perceptions, Social and Economic Conditions}

Adaptive management that includes deliberative processes beyond public hearings for gathering information 
about stakeholder concerns, social and economic conditions can increase decision making capacities. In managing the larger floodplain system, science and technologies must be linked to social values if social learning is to occur and build resilience under uncertainty [34]. There are a variety of social science tools for assessing economic conditions, stakeholder values, willingness to participate in incentive programs, impacts of rules and regulation, perceptions of threats to physical safety, vulnerability of livelihoods to increased weather uncertainty, and evaluation of agency proposed technical solutions [36]. For example, Sorice et al. [35] survey of landowners find that program design and delivery of voluntary conservation programs influenced willingness to participate in adding biodiversity to their land management plans. This kind of information could be particularly valuable in developing policies and programs that combine agricultural production with wetland management that reconnects the floodplain to the hydrology of the river.

Citizen assessments and participation in public decision making often reveal current and emerging divergent opinions that can lead to polarized positions as well as bring to light areas of agreement and common ground. Stakeholder consensus on levee and floodplain ecosystem management is highly unlikely in most instances, however understanding the heterogeneity of fears and motivations for how land is managed recognizes the variety of preferences, attitudes and cultures and can lead to creative collaborative solutions [44]. This information can help guide agency and public decision makers in negotiating solutions congruent with local values and increase policymakers' understanding of stakeholder fears and concerns associated with threats to safety and livelihoods as well as conflicting interests associated with restoration of river habitats and agricultural land uses.

Assessment tools such as surveys and listening sessions are particularly effective when findings are shared with stakeholders and presented in combination with biogeophysical and ecosystem data and the problems associated with managing the floodplain. Providing various stakeholders access to information including facts derived from science about climate and weather patterns, river hydrology, soil and agronomic factors, levee structures, and bottomland ecosystems increases local knowledge and understanding of the landscape level problem. Further, public forums offer stakeholders opportunities to contribute their experiential knowledge and engage in dialogues about what the problem is, impacts on their livelihoods and strategies for addressing and adapting to changing conditions [36].

Stakeholder assessment and engagement can encompass use of web sites and social media to make factual, accurate data accessible and gather feedback in a timely manner. However, this forum of exchange is not a substitute for creating and strengthening local and regional relationships and networks. Workshops, public meetings, goal-oriented committees, and public spaces for informal discussions can build trust and offer venues for exploring and negotiating solutions among divergent, competing values and interests and meet multifunctional goals.

\section{Conclusion}

Every watershed on the Mississippi River has to deal with significant flooding during the rainy season with or without levee breach issues. Knowledge gained from past episodic disasters can break down barriers to change and become a source of new information used to reframe future decisions as public agencies, private organizations and citizens work to prepare for future ecosystem disruptions [45]. Levees have been a valuable infrastructure in protecting the productivity of agriculture in riverine bottom lands, however they may be inadequate as the distribution, seasonality and intensity of precipitation patterns change. Good well et al. [42] call for the restoration of the large-river floodplains utilizing the natural ecosystem to mitigate flood hazard and risks associated with climate change. Wholly returning leveed river bottomlands to their original wetland state has political, social and economic barriers that make this change in land use highly unlikely under current conditions. However, as government agencies, technical advisors and society better understand the ecological functions of the riverine floodplain - the roles that hydrology, wetlands, and soils play in filtering, absorbing, and storing flood water - there may be an increased willingness to adapt and "live with floods" [2]. Social-ecological systems are dynamic and continually adapting (and mal-adapting) in unpredictable ways. While focus on risks to levee design may meet goals of efficiency and temporarily hold equilibrium, additional agroecosystem strategies are needed to build resilience that balance social, economic, and ecosystem vulnerabilities. Taken together, assessments of stakeholder values, knowledge and willingness to adapt and assessments of changing soil conditions and other ecosystem functions are essential feedback information to the scientific analytics and deliberative processes necessary to guide planning and adaptive management for future uncertainties. 


\section{Acknowledgements}

Partial support for this research was provided by the Iowa Agriculture and Home Economics Experiment Station, College of Agriculture and Life Sciences at Iowa State University and in cooperation with North-Central Regional Project No. 1190, Catalysts for Water Resource Protection and Restoration: Applied Social Science Research. Additional funding support comes from Regional Research Project No. 15-372 and in cooperation with NorthCentral Regional Project No. NCERA-3 Soil Survey; and published with funding support from the Director of the Illinois Office of Research, ACES, University of Illinois, Urbana, IL.

\section{References}

[1] Coumou, D. and Rahmstorf, S. (2012) A Decade of Weather Extremes. Nature Climate Change, 2, 491-496.

[2] Wisner, B., Blaikie, P., Cannon, T. and Davis, I. (2004) At Risk: Natural Hazards, People’s Vulnerability and Disasters. 2nd Edition, Routledge, New York.

[3] Mileti, D.S. (1999) Disasters by Design: A Reassessment of Natural Hazards in the United States. Joseph Henry Press, Washington, D.C.

[4] Gopalakrishnam, C. (2013) Water and Disasters: A Review and Analysis of Policy Aspects. International Journal of Water Resources Development, 29, 250-271.

[5] McBean, G. and Rodgers, C. (2010) Climate hazards and Disasters: The Need for Capacity Building. Advanced Review, 1, 871-884.

[6] Bates, B.C., Kundzewicz, Z.W., Wu, S. and Palutikof, J.P. (2008) Climate Change and Water. Technical paper of the Intergovernmental Panel on Climate Change, IPCC Secretariat. Intergovernmental Panel on Climate Change, Geneva.

[7] Romero-Lankao, P., Smith, J.B., Davidson, D., Diffenbaugh, N., Kinney, P., Kirshen, P., Kovacs, P. and Ruiz, L.V. (2014) North America. In: Climate Change 2014: Impacts Adaptation and Vulnerability, Volume II: Regional Aspects Ch 26, IPCC 5th Assessment Report WG11 AR 5.

[8] Olson, K.R. and Morton, L.W. (2012) The Impacts of 2011 Man-Induced Levee Breaches on Agricultural Lands of the Mississippi River Valley. JSWC, 67, 5A-10A.

[9] Walker, B. and Salt, D. (2006) Resilience Thinking: Sustaining Ecosystems and People in a Changing World. Island Press, Washington, D.C.

[10] Park, J.T., Seager, P., Rao, S.C., Convertino, N. and Linkov, I. (2012) Integrating Risk and Resilience Approaches to Catastrophe Management in Engineering Systems.

[11] Morton, L.W. and Olson, K.R. (2013) Birds Point-New Madrid Floodway: Redesign, Reconstruction and Restoration. JSWC, 69, 35A-40A.

[12] Committee on US Army Corps of Engineers Water Resources Science, Engineering and Planning; Water Science and Technology Board, WSTB; Division on Earth and Life Studies, DELS; National Research Council, NRC (2012) Corps of Engineers Water Resources Infrastructure: Deterioration, Investment or Divestment. National Academies Press, Washington, D.C. http://www.nap.edu/catalog.php?record_id=13508

[13] Barry, J.M. (1997) Rising Tide: The Great Mississippi Flood of 1927 and How It Changed America. Simon \& Schuster, New York.

[14] Lowery, B., Cox, C., Lemke, D., Nowak, P., Olson, K.R. and Strock, J. (2009) The 2008 Midwest Flooding Impact on Soil Erosion and Water Quality: Implications for Soil Erosion Control Practices. JSWC, 64, 166A.

[15] Olson, K.R. (2009) Impacts of 2008 Flooding on Agricultural Lands in Illinois, Missouri and Indiana. JSWC, 64,167A$171 \mathrm{~A}$.

[16] Londono, A.C. and Hart, M.L. (2013) Landscape Response to the International Use of the Birds Point New Madrid Floodway on May 3, 2011. Journal of Hydrology, 489, 135-147. http://dx.doi.org/10.1016/j.jhydrol.2013.03.010

[17] Olson, K.R. and Morton, L.W. (2012) The Effects of 2011 Ohio and Mississippi River Valley Flooding on Cairo, Illinois Area. JSWC, 67, 42A-46A.

[18] Olson, K.R. and Morton, L.W. (2013) Restoration of 2011 Flood Damaged Birds Point-New Madrid Floodway. JSWC, 69, 13A-18A.

[19] Olson, K.R. and Morton, L.W. (2013) Impacts of 2011 Len Small Levee Breach on Private and Public Lands. JSWC, 68, 89A-95A.

[20] Olson, K.R. and Morton, L.W. (2013) Soil and Crop Damages as a Result of Levee Breaches on Ohio and Mississippi Rivers. Journal of Earth Science and Engineering, 3, 1-20.

[21] USACE, US Army Corps of Engineers (2010) National Report: Responding to National Water Resources Chal- 
lenges .USACE Civil Works Directorate, Washington, D.C.

http://www.building-collaboration-for-water.org/Documents/nationalreport_final.pdf

[22] Olson, K.R., Lang, J.M., Garcia-Paredes, J.D., Majchrzak, R.N., Hadley, C.I., Woolery, M.E. and Rejesus, R.M. (2000) Average Crop, Pasture and Forestry Productivity Ratings for Illinois Soils. Bulletin 810, University of Illinois, ACES, Urbana-Champaign, Urbana.

[23] Olson, K.R. and Lang, J.M. (2000) Optimum Crop Productivity Ratings for Illinois Soil Average Crop, Pasture and Forestry Productivity Ratings for Illinois Soils. Bulletin 811, University of Illinois, ACES, Urbana-Champaign, Urbana.

[24] Chormanski, J., Okruszko, T., Ignar, S., Batelaan, O., Rebel, K.T. and Wassen, M.J. (2011) Flood Mapping with Remote Sensing and Hydrochemistry: A New Method to Distinguish the Origin of Flood Water during Floods. Ecological Engineering, 37, 1334-1349. http://dx.doi.org/10.1016/j.ecoleng.2011.03.016

[25] Camillo, C.A. (2012) Divine Providence: The 2011 Flood in Mississippi River and Tributaries Project. The Mississippi River Commission, Vicksburg.

[26] Flood Control Act, FCA (1928). http://www.mvd.usace.army.mil/Portals/52/docs/MRC/Appendix_E._1928_Flood_Control_Act.pdf

[27] Rahm, C. (2013) Bootheel Adds More Wetland Acres and Wetlands Help Mitigate Flooding. Missouri Ruralist, 60. www.FarmProgress.com

[28] US Census of Agriculture United States Department of Agriculture (2013) http://agcensus.usda.gov/index.php/

[29] Hatfield, J. and Morton, L.W. (2013) Marginality Principle. In: Lal, R. and Stewart, B.A., Eds., Principles of Sustainable Soil Management in Agroecosystems. Advances in Soil Science, Taylor \& Francis, CRC Press, New York, 19-55.

[30] Bruneta, R.C. and Astin, K.B. (2008) A Comparison of Sediment Deposition in Two Adjacent Floodplains of the River Adour in Southwest France. Journal of Environmental Management, 88, 651-657. http://dx.doi.org/10.1016/j.jenvman.2007.03.042

[31] Bendix, J. and Hupp, C.R. (2000) Hydrological and Geomorphological Impacts on Riparian Plant Communities. Hydrological Processes, 14, 2977-2990. http://dx.doi.org/10.1002/1099-1085(200011/12)14:16/17<2977::AID-HYP130>3.0.CO;2-4

[32] McCleland, J. (2013) Nobody Fully Satisfied with St. Johns Bayou-New Madrid Floodway Draft EIS. KRCU. http://krcu.org/post/nobody-fully-satisfied-at-johns-bayou-new-Madrid

[33] USACE, US Army Corps of Engineers Memphis District (2013) East Prairie, Missouri Public Hearing for the Draft Environmental Impact Statement on St. Johns Bayou-New Madrid Floodway Project.

[34] Dietz, T. (2013) Bringing Values and Deliberation to Science Communication, PNAS, 110, 14081-14087. http://dx.doi.org/10.1073/pnas.1212740110

[35] Sorice, M.G., Oh, D.O., Gartner, T., Snieckus, M., Johnson, R. and Donlan, C.J. (2013) Increasing Participation in Incentive Programs for Biodiversity Conservation. Ecological Applications, 23, 1146-1155. http://dx.doi.org/10.1890/12-1878.1

[36] Morton, L.W. and Brown, S.S. (2011) Pathways for Getting to Better Water Quality: The Citizen Effect. Springer Science + Business, New York.

[37] Chapin, F.S., Carpenter, S.R., Kofinas, G.P., Folke, C., Abel, N., Clark, W.C. , Olsson, P., Smith, D.M.S. Walker, B., Young, O.R., Berkes, F., Biggs, R., Grover, J.M., Naylor, R.L., Pinkerton, E., Steffen, W. and Swanson, F.J. (2009) Ecosystem Stewardship: Sustainability Strategies for a Rapidly Changing Planet. Trends in Ecology and Evolution, 25, 241-249.

[38] McLaughlin, D. and Cohen, M.J. (2013) Realizing Ecosystem Services: Wetland Hydrologic Function along a Gradient of Ecosystem Condition. Ecological Applications, 23, 1619-1631. http://dx.doi.org/10.1890/12-1489.1

[39] Bormann, H., Pinter, N. and Elfert, C. (2011) Hydrological Signatures of Flood Trends on German Rivers: Flood Frequencies, Flood Heights and Specific Stages. Journal of Hydrology, 404, 50-66. http://dx.doi.org/10.1016/j.jhydrol.2011.04.019

[40] Schmocker-Fackel, P. and Naef, N. (2010) Changes in Flood Frequencies in Switzerland Since 1500. Hydrology and Earth System Sciences, 14, 1581-1594. http://dx.doi.org/10.5194/hess-14-1581-2010

[41] Changnon, S.A., Kunkel, K.E. and Andsager, K. (2001) Causes for Record High Flood Losses in the Central United States. Water International, 26, 223-230. http://dx.doi.org/10.1080/02508060108686908

[42] Goodwell, A.E., Zhu, Z., Dutta, D., Greenberg, J.A., Kumar, P., Garcia, M.H., Rhoads, B.L., Holmes, R.R., Parker, G., Berretta, D.P. and Jacobson, R.B. (2014) Assessment of Floodplain Vulnerability during Extreme Mississippi River Flood 2011. Environmental Science Technology, 48, 2619-2625. http://dx.doi.org/10.1021/es404760t 
[43] National Academies (2012) Disaster Resilience Committee on Increasing National Resilience to Hazards and Disasters. Committee on Science, Engineering and Public Policy. The National Academies Press, Washington, D.C.

[44] Brown, T. (2009) Change by Design. Harper Collins, New York.

[45] Sidle, R.C., Benson, W.H., Carriger, J.F. and Kamai, T. (2013) Broader Perspective on Ecosystem Sustainability: Consequences for Decision Making. PNAS, 110, 9201-9208. http://dx.doi.org/10.1073/pnas.1302328110 
Scientific Research Publishing (SCIRP) is one of the largest Open Access journal publishers. It is currently publishing more than 200 open access, online, peer-reviewed journals covering a wide range of academic disciplines. SCIRP serves the worldwide academic communities and contributes to the progress and application of science with its publication.

Other selected journals from SCIRP are listed as below. Submit your manuscript to us via either submit@scirp.org or Online Submission Portal.
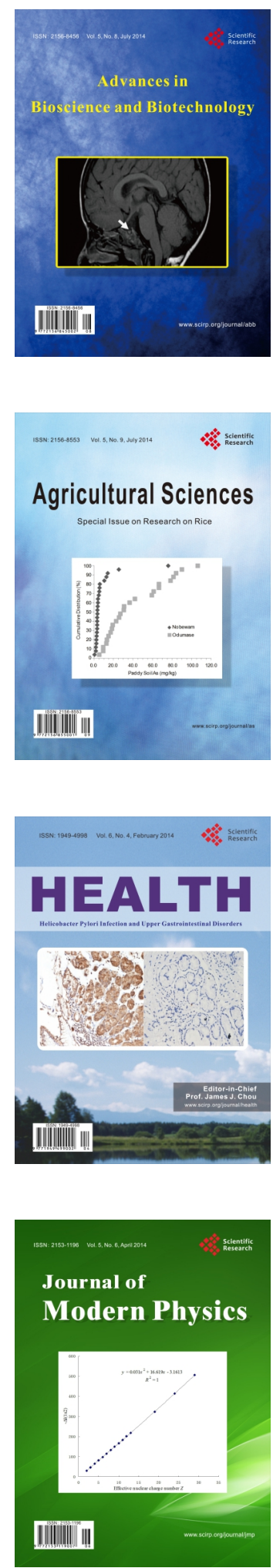
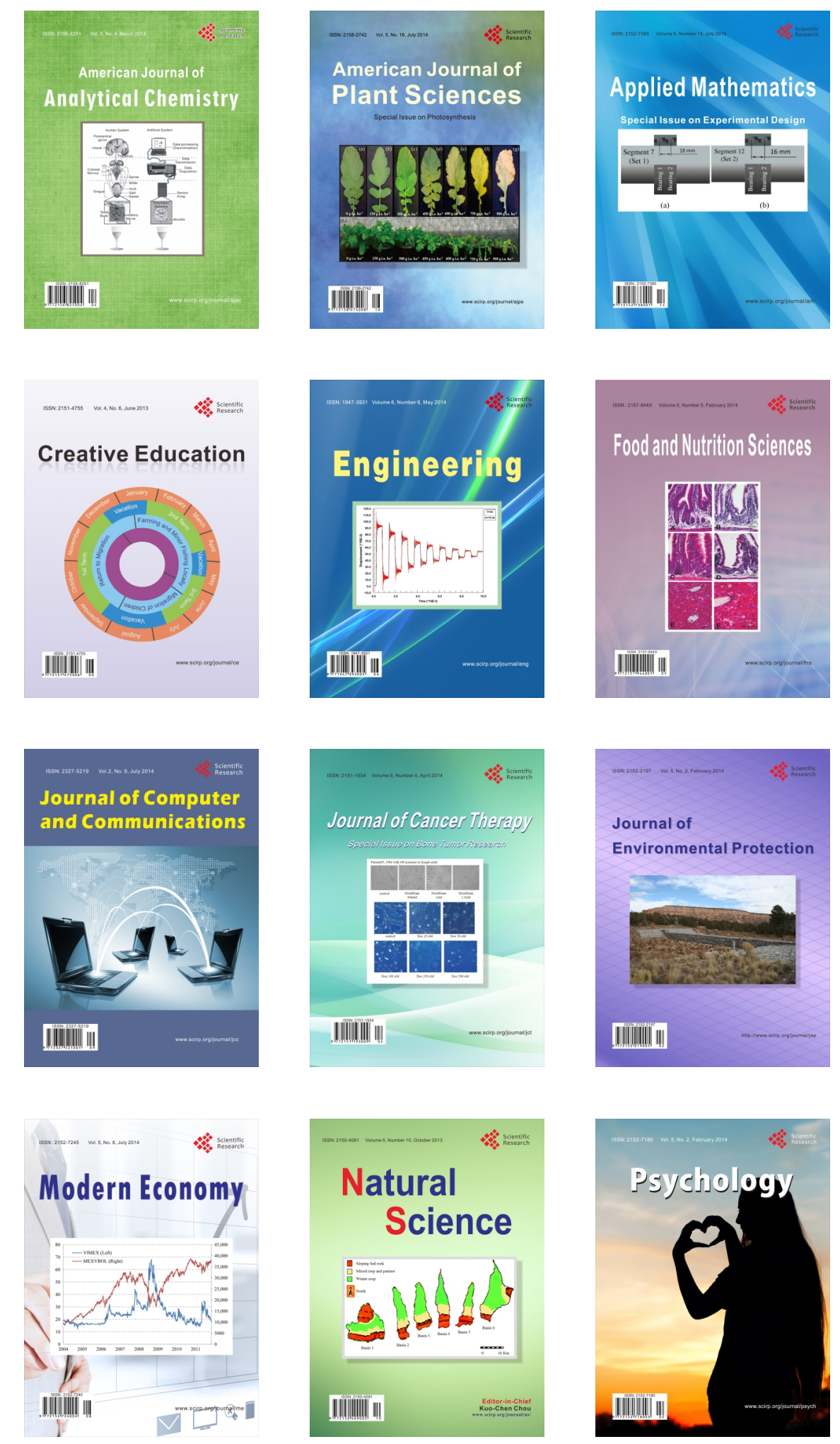